\section{FILM OR FLICK?: BUNDIT RITTAKOL'S YOUTH FILMS AS A REFLECTION OF RESISTANCE TO SOCIO- CULTURAL TRANSITION IN THAILAND ${ }^{1}$}

\section{Thanayod Lopattananont ${ }^{2}$}

บทคัดย่อ

การวิจัยครั้งนี้มุ่งศึกษาภาพยนตร์วัยรุ่นโดยบัณฑิต ฤทธิ์ถกลจำนวนทั้งสิ้น ๑๐ เรื่อง ออกฉายช่วงปีพ.ศ. ๒๕เ๒๓-๒๕๕๓ เป็นการศึกษาในกรอบทฤษฎีที่ว่าสื่อ ภาพยนตร์สามารถทำหน้าที่ประหนึ่งเครื่องมือสะท้อน สังคม-วัฒนธรรม เพื่อเข้าใจความสัมพันธ์ระหว่างตัว ภาพยนตร์และการเปลี่ยนแปลงทางสังคม-วัฒนธรรม ในช่วงเวลาที่แต่ละเรื่องออกฉาย ซึ่งเป็นระยะที่

1 (สาระหรือบันเทิง? : ภาพยนตร์วัยรุ่นโดยบัณฑิต ฤทธิ์ถกลในฐนะ ภาพสะท้อนการเปลี่ยนผ่านทางสังคม-วัฒนธรรมในประเทศไทย)

This article is based on the author's $\mathrm{PhD}$ dissertation entitled Film or Flick? : Bundit Rittakol's Youth Films as a Reflection of Socio-Cultural Transition in Thailand, partially funded by (1) Film Archive (Public Organization) and (2) the Empowering Network for International Thai Studies (ENITS), Institute of Thai Studies, Chulalongkorn University, with support from the Thailand Research Fund (TRF).

2 (ฐนยศ โล่ห์พัฒนานนท์) Thanayod Lopattananont recently received his $\mathrm{PhD}$ from Chulalongkorn University and is now a part-time lecturer in the Faculty of Communications Arts, Chulalongkorn University.
สังคมไทยกำลังเปลี่ยนผ่านทั้งในแง่เศรษฐูกิจและ สังคมอันเป็นผลสืบเนื่องมาจากพัฒนาตามแนวทาง เศรษฐิกิจเสรี โดยมี โลกาภิวัตน์และการยกระดับ ประชาธิปไตยเป็นปัจจัยส่ง

ขณะที่สื่อหลักจำนวนไม่น้อยนำเสนอเนื้อหา สอดคล้องกับการเปลี่ยนผ่าน ภาพยนตร์วัยรุ่นโดย บัณฑิต ฤทธิ์ถกลกลับสวนกระแสที่ว่า โดยตีความได้ จากแก่นการนำเสนอสามประการ เริ่มจากแก่นที่หนึ่ง เป็นการแสดงตัวละครวัยรุ่นผ่านภาพของเยาวชนใน อุดมคติ มีลักษณะตามแบบธรรมเนียมไทยเละไม่ โอน อ่อนผ่อนตามวิถีชีวิตสมัยใหม่ แก่นที่สองคือการแสดง ภาพสังคมสมัยใหม่ในด้านลบ โดยการเชื่อมโยง องค์ประกอบต่างๆที่สื่อถึงความนำสมัยทางสังคมเศรษฐึิจกับตัวละครในบทร้ายรวมทั้งเชื่อมโยงกับการ กระทำหรือเหตุการณ์ที่ก่อให้เกิดผลร้ายต่างๆ ในทาง ตรงข้าม แก่นที่สามย้ำเน้นอะไรก็ตามที่บัณฑิตมองว่า เป็นด้านบวกของความเป็นไทย โดยเฉพาะความเป็น ไทยกระแสหลัก ดังเช่น วิถีชีวิตเกษตรกรรมที่ดูงดงาม หรือศรัทธาอันแรงกล้าในพระพุทธศาสนา ในหลายๆ ครั้งบริบททางวัฒนธรรมที่แลดูมีความจำเพาะสำหรับ สังคมไทยถูกผูกเข้ากับตัวละครหลัก ประหนึ่งย้ำเตือน ให้ผู้ชมได้ระลึกถึงเอกลักษณ์ไทยจากมุมมองแบบ จารีตนิยม จากเหตุผลเหล่านี้ บัณฑิตเลือกที่จะไม่ ประนีประนอมกับการเปลี่ยนแปลงที่กำลังครอบคลุม สังคมไทยในช่วงเวลานั้นจึงสรุปได้ว่าภาพยนตร์วัยรุ่น ของบัณฑิตเป็นงานซึ่งขัดขืนกระแสโลกาภิวัฒน์ด้วย ภาพสะท้อนความเป็นท้องถิ่นไทย 


\begin{abstract}
Based on the theory that the film medium is of high value in reflecting socio-cultural matters, this research studied ten youth films directed by Bundit Rittakol during the 1980s-2000s in order to provide an understanding of how his films can be associated with the socio-cultural changes occurring at that time. During the 1980s2000s, Thai society went through a period of economic and social transition with the adoption of a liberalized economy, influenced by globalization and democratization.
\end{abstract}

Many mainstream media outlets have provided content that has tended to support these socio-cultural changes, but Bundit Rittakol's youth films speak against this transition as can be interpreted from the themes that can be found in the films. The first theme is the projection of the central youth characters having what many consider to be 'desirable' characteristics, mostly in conformity to traditional Thai behavior and rejecting the changing lifestyle of that time. The second theme concerns the negative portrayal of modern society in which elements indicative of socio-economic modernism and change are associated with characters in antagonistic roles or actions or events that result in unfavorable consequences. The final theme stresses what Bundit deemed to be positive images of mainstream Thainess, such as an idealized agricultural lifestyle or strong faith in Buddhism. At times, specific cultural contexts are depicted in association with key characters as if to remind the audience of the Thai identity from a traditional perspective, meaning that Bundit chose to not compromise with the changes that were predominant in society at that time. Therefore, it can be concluded that his youth films provided a view that countered the impact of globalization by using a localization of images as a reflection of resistance.

\section{Introduction}

Youth film ${ }^{3}$ is typically viewed as a work of entertainment created primarily to maximize box office receipts. Such films have become a significant part of Thai cinema since the successful screening of Somboonsuk Niyomsiri's Wai A-luan [วัย อลวน] in 1976. Many directors have not hesitated to produce films in this genre in the hope of achieving a similar reception. One of them was Bundit Rittakol who directed ten youth films during the 1980s2000 s and also co-directed two other films. Some of his youth films, such as Bunchu Phu Narak [บุญชูู้น้ารัก] (1988), which grossed 14 million baht, much more than any youth films released previously were quite successful at the box office.

\footnotetext{
${ }^{3}$ A youth film has a story that centres around youth characters and their experiences. According to Driscoll (2011: 2), youth film can be identified by content rather than the form or style. This content is often about the youthfulness of central characters, puppy love, strong age-based peer relationships, conflict with friends or senior people, and such. 'Youth' is usually defined as those aged 15-24, or thereabouts, sometimes without specification of like age, but generally of the period of growing into maturity. Therefore, 'youth film' is a genre about and for people in this age span.
} 
Some others won awards for their quality, as in the case of Anueng Khitthueng Pho Sangkhep [อนึ่งคิดถึงพอสังเขป] (1992), which was named Best Film at the Supannahong Film Award Ceremony.

Two authors have explored Bundit's youth films from the angle of film and society. Thasanabanchong (2010: 230-231) discusses the significance of each Bunchu film as part of her article, 'A Study of Themes in Contemporary Thai Teenage Films', asserting that all the Bunchu films contain a theme that overtly reflects Thai society. These films are, for that reason, not pure comedies, as in the general notion, but have a socio-cultural genuineness worth attention. Another work by the same author is The Analytical Study of the Characteristics of Thai Popular Youth Movies (1991) where nine films from different directors including Bunchu Phu Narak and Bunchu Two, Nongmai are taken as representative samples. Thasanabanchong wrote that many films supply the concept of camaraderie wherein the young shared dreams, generosity and sacrifice. Bunchu Phu Narak and Bunchu Two, Nongmai are amongst these films with the strong intent to show this aspect of youth. In a thesis entitled The Narrative of Thai Popular Comedy Film Series "Bunchu" and the Director's Creative Approaches, Chummuangpak (2004) discusses how the Bunchu series can be identified as good quality films through the incorporation of social concerns, especially, those that Thai people regularly experience, such as a lessening of generosity.
Although these two authors broke new grounds on Bundit's youth films, other studies of this nature have rarely been conducted. According to Boonyaketmala (2009: 30), Thai scholars hold a limited worldview concerning the study of film, whereby they consider film to be simply a tool for relaxation without social significance.

According to Kolker (2006: 255), film is a product, as well as a promoter, of social ideology and cultural desire. A film can, therefore, be an effective reflector of socio-cultural matters regardless of its category. By adopting this view, this research was conducted in order to understand the significance of Bundit's youth films, and led to the discovery that each of his films has a greater function than common entertainment, furthering the findings set forth in the work of Thasanabanchong and Chummuangpak. The films included in this research feature youth characters who possess the ideal traits promoted by some traditionalists. The films also depict social problems as part of the setting, as well as stressing traditional convictions, such as interdependence, forgiveness or the pursuit of an agrarian way of life. It is apparent that, in addition to trying to entertain the audience, Bundit Rittakol intended to focus on purposive messages with reference to Thai society and culture. Some of the messages are made explicit on screen, but some require careful analysis. The intention of this research is, thus, to deepen the knowledge of all Bundit's youth films as a reflection of society and culture and to examine the link between this group of films and the Thai socio- 
cultural climate at that time and, therefrom, to reveal the meaning of the films beyond mere 'marketing' or 'entertaining'.

\section{Selected Films}

This research focused on the youth films directed by Bundit Rittakol alone and did not consider any of his films that concentrated on the life of mature characters. The films included in this study are:

1. Khu Wun Wai Wan [คู่วุ่นวัยหวาน] (1986)

2. Bunchu Phu Narak [บุญชูผู้น่ารัก] (1988)

3. Bunchu Two, Nongmai [บุญชูสองน้อง ใหม่] (1989)

4. Bunchu Five, Nueahom [บุญชูห้าเนื้อ หอม] (1990)

5. Bunchu Six, Lok Ni Di Ok Sutsuai Narak Nayu Tha Ngui [บุญชูหกโลกนี้ดี ออกสุดสวยน่ารักน่าอยู่ถ้าหงุ่ย] (1991)

6. Anueng Khitthueng Pho Sangkhep [อนึ่งคิดถึงพอสังเขป] (1992)

7. Anueng Khitthueng Pho Sangkhep Run Two [อนึ่งคิดถึงพอสังเขปรุ่นสอง] (1996)

8. Chue Chop Chuan Ha Rueang [ชื่อ ชอบชวนหาเรื่อง] (2003)

9. Bunchu I Love Sara Ou [บุญชูไอเลิฟ สระอู] (2008)

10. Anueng Khitthueng Pen Yangying [อนึ่งคิดถึ่งเป็นอย่างยิ่ง] (2009)

\section{Thai Society in Transition}

In explaining Thai social aspects, Changrean (1971: 4) refers to 'A Model for the Study of Thai Society' (published in the Thai Journal of Public Administration, April 1961) which states that Thai society was originally a traditional society in which people's lives were largely dependent on the natural environment. Traditional Thai society has also been called an 'agrarian society' with its many rituals or ceremonies concerning agriculture, such as Making Mysterious Principle According Rice (ทำขวัญข้าว) or The Royal Ploughing Ceremony (แรกนาขวัญ) (Sengpracha, 2001: 23). People in an agrarian based society tend to live as a group embracing interdependence and compromise in order to maintain a community spirit and a sense of togetherness. In contrast to the traditional agrarian social model, the adoption of a liberalized economy as well as globalization and democratization, have resulted in heavy development, ending in greater urbanization, industrialization and capitalist/consumerist expansion.

Urbanization in Thailand started at a serious level with the implementation of the National Economic and Social Development Plan in 1961, which was conceived upon the notion that the rural sector was a key impediment to the nation's development (Sukkumnoed, 2011: 76). Such urban development proceeded at a moderate level until the late 1980s when there was an acceleration of the concentration of industries, construction, and businesses in urban areas, causing a significant growth in the disparity between 
the urban centers, such as Bangkok, and the rural areas.

Thai industrialization was stimulated by the belief that more industrial development would put an end to poverty and unemployment. Therefore, the government kept attracting foreign investors through a market-friendly approach in order to achieve the targeted increase of industries (Kohpaiboon, 2006: 72). Thailand was recognized as the new tiger of Asia due to this unexpected growth of the industrial sector that occurred over a short period (Puapongsakorn, 1999: 8).

To facilitate capitalist expansion, the government decided to boost the domestic finance industry. In 1993, the government relaxed the foreign exchange system to assist speculative investment (Laird, 2000: 95), while populist policies were devised to enhance the capitalistic ventures in the 2000s. According to a survey by the National Statistical Office of Thailand, the average debt of Thai households changed from 31,387 baht in 1994 to 82,485 baht in 2003 (Krongkaew, 2009: 43). This indicates how much people were urged to spend and consume to energize the economy.

As a result, Thai society began to change more rapidly from an agrarian society to a more modern, industrial society. With agricultural and industrial lifestyles intermingled, people became more economically active and adapted themselves to the new living conditions. This transition resulted in such social changes as a reduction of family size, the ready adoption of popular culture from both the West and East and reliance on enhanced technology.

In this climate, many young people tried to differentiate themselves from the former generation, more specifically, the young in the 1970s who were notable for their socio-political activism. Sulak Sivaraksa analysed the young people in the 1980s and noted that they were discouraged from individual thinking and, rather, were encouraged to have an imitative tendency (Chamduang, n.d.: 200-206). The 1980s youth shared a culture that was concerned with acquiring luxurious items or engaging in entertainment, such as visiting discotheques, bowling centers and the like (Setihoe, 1989: 97). According to a report by the Board of Educational and Training Development for Teenagers (1992: 22), the number of young people aged 15-19 with psychological problems increased dramatically. Research findings obtained by Boribanbanpotkate and Ptanawanit (1995: 102-103) reveal that children and young people had an increased inclination to commit crimes, including robbery, murder, attempted murder, assault, and sexual offenses. Nakornthap (2004: 2021) pointed toward many radical features adopted by young people, including excessive consumption, promiscuous sex and illegal drug use. Kumprabhan and Kaewseenuan (2004: 42) discovered that the young had rising aggression, with assaults by students becoming more and more prevalent as a result of increasing emotional instability as well as depression.

These social phenomena contradicted the desirable qualities of young people as set forth in Pienchob's research (1982). 
Sucharit defined desirable qualities as being in possession of sound morals, being ethical, acting efficiently and remaining compliant with Thai traditions, such as honoring the seniority system and following local customs. Sucharit claimed these desirable qualities could foster emotional stability, thinking capacity, morality, and the realization of Thai culture. However, the young appeared to rather enjoy the new cultural environment which focused on consumption and pleasure-seeking, along with challenges to existing social controls and a new found sense of freedom.

Change, both in youth and in the social context, continued in proportion to the ongoing development to which mass media made an enormous contribution. This can be exemplified by Thai film, many of which feature protagonists as conformists to the modern lifestyle. An outstanding example is Phuying Kon Nan Chue Bunrod [ผู้หญิงคนนั้นชื่อบุญรอด] (dir. Wijit

Kunawut, 1985) where the quest for wealth is represented as the way out of despair, or Wongsakhanayat [วงศาคณาญาติ] (dir. Jazz-Siam, 1987) the theme of which is based on the idea of individualism, and branding the extended family as primitive.

Some scholars and thinkers did not agree with the changes. According to Piampongsarn and Kaewthep (2000: 159165), these scholars can be categorized into two groups according to the difference in their conceptual foundation. The first group includes those who subscribe to the idea of 'community culture' stemming from the collaboration of thinkers including Phra Dhampidok,
Wibool Kemchaloem, Prawase Wasi, Chattip Natsupa, Ekawit Nathalang and Naowarat Pongpaibul. The 'community culture' group generally displayed a negative opinion to the process of globalization. They were critical of globalization for weakening Thai communities, as well as causing unnecessary dependence on the international economy and advanced technology. The way forward, as put forth by this camp, was the self-sufficiency economy in conjunction with Buddhist economics, whereby Thai society had to integrate 'spiritual culture' into its economic system, along with generosity, with mutual assistance among people in each community being promoted. The ability to live in harmony and balance with nature, plus living modestly, had to be included to sustain the moderate consumption of natural resources, as well as the correct conservation of nature. The last point stressed by this camp was a revival of Thai identity, such as in culture, local wisdom, the role of the Buddhist temple and the privilege of villagers to make their own decisions.

The second group are those who espouse 'democratic liberalism' which encompasses intellectuals and retired bureaucrats, including Chai-Anan Samudavanija, Amorn Chantarasomboon, Saiyud Kerdphol and Ammar Siamwalla. The central tenet of this group was political reform in the promotion of popular opinions. They did not object to the concept of the liberal economy but supported sharing fundamental decisions at every level - from the state to the community. Globalization, in the eyes of 
this camp, was inevitable. They believed that Thailand ought to adapt itself to globalization, rather than react with an unanimous rejection - for instance to join the free market economy with transparency or to recognize a community as a secondary dynamism for social advancement.

In terms of how these social and economic changes were reflected in films, directors responded to the aforesaid transition through different film genres and in different ways. With respect to one such genre, youth films, Bundit is interesting to study because the subject matter of Bundit's films is often about the young and the way they deal with the transition.

\section{Bundit Rittakol's Youth Films: Themes of Representations ${ }^{4}$}

\section{Khu Wun Wai Wan}

Bundit's first youth film, Khu Wun Wai Wan, projects the message that young people who fail to conform to the expected attitude and behavior of Thai youth will never experience true happiness. This is conveyed through the depiction of the four main characters: Meen, Jeab, Jaeng and Aom. The focus is on Meen who exhibits delinquent, selfish behavior and, therefore, struggles to receive social acceptance. The other three characters experience trouble after they violate the concept of what is considered good youth in a Thai context, such as engaging in romance without proper emotional control. It

\footnotetext{
${ }^{4}$ Plotlines of each film are set forth in the appendix.
}

cannot, however, be denied that these three characters are also designed to represent the idea of how the young should behave. This is most apparent in Jeab who is portrayed as exceptionally polite and kind, while Jaeng and Aom maintain a lifestyle devoid of delinquency throughout the story. Meen can be considered another character promoting the concept of ideal youth because the story is about his change of behavior from bad to good which results in his being loved by the people whom he cares about. In addition, Jaeng, Aom and Meen have the image of being attentive students, implying that youth should be seriously responsible about education.

Khu Wun Wai Wan also contains a link between the modern state of Thai society and amorality, including the misbehavior of young people. The antagonists Wongwai and the headmaster, who represent modern-acting people cooperate in cheating on a scholarship test. Also, many young characters who live an urban lifestyle engage in improper behavior. Some places suggestive of a modern way of life, such as a billiard club, a sports club and a high class restaurant, become locations for the delinquent activities of the young characters. In contrast, some elements indicative of what is considered to be a good Thai are portrayed in a way that delivers a good feeling. For example, Jeab survives a threat from Wongwai because of help from various minor characters, many of whom do not even know him. This signifies the value of interdependence, a common tradition found in agricultural society. Jeab, who is a highly ethical 
character, lives in a traditional Thai style house; but no scenes depict the antagonists in a similar style house. The grandfather of Jeab and Jaeng, who looks typically Thai, represents morality, in contrast to Wongwai who looks more modern. This projects a positive image of being a proper Thai.

\section{Bunchu Phu Narak}

The message speaking against change is even clearer in Bundit's second youth film, Bunchu Phu Narak, through the portrayal of the key youth characters: Bunchu, Moree, Chuey, Waiyakorn, Nara, Kummoon and Yoi. As a whole, their attitudes and behavior conform with the concept of ideal youth, not widely followed by the general young population. They remain as a group and no individual heroism can be seen because of their mutual help for each other. They concentrate on preparation for the university entrance exam, as well as avoiding lifestyles that may distract them from their educational obligations. Their gatherings are very simple and safe. They remain friendly and kind to one another in all the scenes in which they appear. Bunchu and Moree appear more outstanding than the others in terms of representing good youth. Even though from different social backgrounds, both are similarly courteous, polite and conscientious. They are capable of emotional control, including the proper management of their romance. Bunchu, for example, is able to forget his love interest in order to concentrate on studying when his mother, Bunlom, expresses concern about his preparations for the exam. Moree herself treats Bunchu kindly no matter how he reveals his love towards her. At the same time, she does not do anything to lure him into romance.

In tandem with emphasizing the image of good youth, Bunchu Phu Narak contains a message that is critical of Thailand's urbanization through a plotline that has Bunchu endure the meanness of city people when he resides in Bangkok. For example, he loses his belongings after his arrival in the capital and he is bullied by the city youth. As well as Bunchu's unfortunate situations, many scenes tend to project the idea that there is a relationship between the adoption of a foreign culture and undesirable behavior in modern Thai society. All the antagonists serve as an example - their delinquency is often depicted in association with clothing, props, or activities representative of popular culture. This plotline and approach to representation communicates the belief that socio-economic modernization does not necessarily end in civilized conduct. Simultaneously, typical symbols, such as ruralness and agriculture, along with cultural signs and landmarks, are incorporated to the story to show opposition to the thought that such identities are old-fashioned. Some symbols are repeatedly used as background settings for the central characters, for instance, the use of the Chao Phraya River as a main site for filming the key characters. Some symbols are present in the story with positive images, as shown in the rural village scenes where warm communal interaction prevails. The character of Bunchu himself, including his family, represents the 
naivety and the beauty of rural people, in order to remind the audience of salient features of non-urban Thais.

\section{Bunchu Two, Nongmai}

Bundit's third youth film, Bunchu Two, Nongmai, constructs an image of ideal young people, again using the same group of central characters, to which Prapun is added as a new member. Bunchu is portrayed as a strict follower of Buddhism and is friendly, modest and obedient. His emotional control remains an outstanding behavioral feature whenever he comes across unexpected problems. He never minds lending a hand to other people. Moree is a kind and friendly person similar to Bunchu and is courteous and shows forgiveness. Responsibility and sincerity are further features seen in her character. Kummoon, Yoi, Nara, Chuey, Waiyakorn and Prapun supplement the representation of good youth with their joyful gatherings and mutual helpfulness. Delinquency is never part of their behavior. As a whole, they have simple lifestyles and rarely engage in popular cultural activities, apart from joining in the celebration of Valentine's Day. Their interest in personal romance is not carried on in a way that affects their educational duty.

With reference to education, Bunchu Two, Nongmai places an emphasis on higher education as the compulsory duty for young Thai people. Accordingly, top state universities turn into the main location for the central characters, with the depiction of an inspiring atmosphere, including extra characters who appear in full uniform and join the university lifestyle without experiencing any trouble. Simultaneously, there is no serious hostility amongst the young at university - friendship and a delightful experience can easily be noticed. This reflects a positive view of Thai higher education.

Thainess, in the classic notion, is integrated into the story quite frequently, and often with a constructive image to evoke the recognition of being Thai. Bunlom, Bualoy, Maha Jam, a senior monk and Bunchuay represent Thai ruralness. There are no misdeeds in their daily living. The portrayal of the rural village with its rice fields, is done with the absence of adversity or amorality in order to connect 'being rural' with 'pleasantness'. The Chao Phraya River, a riverside house and Thai state universities are presented in the story with the aim of highlighting social identity. The lotus is used in a short scene of Valentine's Day as an offering for love to suggest the localization of a foreign tradition.

Conversely, Thailand's socio-economic modernization is depicted in a negative way to project the view that this development has not proceeded properly. Bunma steals money because of poverty resulting from the unequal development between city and rural areas. The characters with urban backgrounds, such as Manee, her employee, and her secretary, seem unkind and hot-tempered, while modern elements, such as Manee's office, a cake and roses, are included in the scenes where some of the characters encounter interpersonal problems.

Bunchu Five, Nueahom 
Representation in Bunchu Five, Nueahom remains the same as in the preceding films. Bunchu is still a strict follower of Buddhism. He is reverent, obedient, polite and friendly, remaining calm in many serious situations. He never attempts to transform his rural nature, even though he lives in an urban setting for his studies. $\mathrm{Ou}$ is an additional character who takes a key role similar to Bunchu and Moree. She has financial problems but never tries to overcome these in an improper way such as by being a prostitute or committing illegal activities in exchange for money. Obedience, courtesy and thoughtfulness are her inherent features. Moree and the rest of the group keep their unity through mutual help, regardless of their different educational institutions. Forgiveness, sympathy, kindness and sincere friendship are always evident in their gatherings, as well as joyful group interaction and lifestyles considered to be suitable for the young. Youthful romance between Bunchu and Moree looks highly idealized as the two carry on with reason rather than emotion. What is very interesting is that there is a slight change to these central characters, insofar as they bear some resemblance to Thai students in the 1970s. They help each other in rectifying a grant problem to relieve Ou's financial hardship, despite having nothing to do with her. Bunchu's desire to study pesticides in order to help farmers and his election campaign, which stresses the fairness of the grant approval process, also brings to mind the social activities of the mid-1970s, in that they show his wish to better society.
What is quite evident in the film is the satirical comment on the state of Thai democracy through the situation concerning student elections. The two candidates - Janpen and Raewat - engage in unfair tactics to win the election. Some extra characters express their thoughts and will not vote for Bunchu, branding him as an old-fashioned candidate, and some feel that Bunchu's goal to rectify the grant is pointless. These suggest the question of whether or not democracy is properly understood in Thai society because voters only think of the look of a candidate and their own personal advantage, while election campaigns are run in an unethical manner. Such a question is most clearly apparent in the scene of Bunma talking about vote buying, saying that no vote should be given if no money is offered.

The contrast between socio-cultural identity and modernity continues in this film. Bunlom, Bunchuay, Bualoy, and Bunma represent the decency of rural society through their harmless and optimistic natures. Rice fields provide the sense of a peaceful nature, in addition to representing agricultural society, while the rural village is a setting for communal interaction. Kasetsart University plays a role in stressing agrarianism through its name and atmosphere. ${ }^{5}$ As well as these, some university student traditions and typical locations, such as the Chao Phraya River or Pi Pong's food stall, are elements stressing specific cultural aspects of Thai

\footnotetext{
${ }^{5}$ The name 'Kasetsart' means agriculture and the school's aim is to advance knowledge in agricultural science, so the university is used to represent Thai rural culture in this film.
} 
society. However, modernity is represented in the opposite fashion, which can be seen when the antagonist misbehaves with his unnecessary expenditure on food and drink. He cannot resist consumption for personal pleasure, which some scholars consider to be a consequence of the changing society. The characters with an urban background, such as Manee, Professor Sutto, Professor Sutto's colleague and Ou's mother, are not as kind and moral as the group of rural characters. Some Bangkok scenes depict a modern lifestyle which suggests the meanness of Bangkokians, such as the scene where Bunchu loses his wallet on a bus. Finally, Bunchu's campaign connotes unequal development in that the agricultural sector is not sufficiently managed by the government. This is indicated in the short scene containing Bunchu's election campaign poster, key messages of which consist of 'agricultural justice group' [กลุ่มเกษตรธรรม] and 'fairness of budget arrangement' [เพื่อความเป็นธรรมในการ รับทุน].

\section{Bunchu Six, Lok Ni Di Ok Sutsuai Narak Nayu Tha Ngui}

Promotion of youth in the ideal sense continues in the next film, Bunchu Six, Lok Ni Di Ok Sutsuai Narak Nayu Tha Ngui, by using the same central characters, with the addition of Tongdee - Bunchu's relative who has just arrived in Bangkok. Development of Bunchu's maturity is, however, more prominently portrayed than in the case of the others. Bunchu takes good care of Tongdee as if he is Tongdee's main guardian, and is selfcontrolled, thoughtful and conscious of love. In one scene, Tongdee's dialogue shows that Bunchu has been an honest, obedient and trustworthy person since he was young. While Bunchu is maturing, Moree becomes a working woman who remains kind, courteous and ethical.

Tongdee's character resembles Bunchu's in many respects. He is polite, harmless and innocent. $\mathrm{He}$ misbehaves in the middle of the story because of his love for the female antagonist, Lalita, but repents and corrects his behavior in the end. The group is kind, thoughtful and mutually supportive, as usual. They are, however, inferior to Bunchu by being able to control their personal romantic feelings for Lalita which leads to the first fragmentation of the group. However, their friendship is quickly restored after Bunchu intervenes in the conflict and warns them. Overall, joyful gatherings, interdependence and a simple lifestyle are the basic aspects of the central youth characters. Some of the characters suggest education as the duty of young people. Proper management of romance and concern for society can be seen through the role of Bunchu and Moree.

Socio-cultural identity in this film is repeatedly depicted to evoke the recognition of being Thai. The rural identity is apparent through the rural nature of the characters, such as Bunchuay, Bunlom, Bunchu's relatives and the senior monk who shows great care and decency. The quaintness of the rural life is stressed by beautified images of rice fields, the country village and the warm and joyful conversations in the rural community. In the Bangkok scenes, locations such as 
Sanam Luang or the Temple of the Emerald Buddha are used as landmarks in place of famous business streets. Many scenes with the central characters are representative of Thai culture, such as the scenes of a riverside house, Pi Pong's food stall, or scenes which feature daily Thai traditions, such as having a typical Thai meal.

On the other hand, elements indicative of modernity suggest a link between modern the lifestyle and problems. Some characters, such as Lalita and her subordinates who have the image of city people, cause trouble for Bunchu and the group throughout the story. Manee's office is a place where the audience can feel a stress that is non-existent in the scenes of the rural area. A lottery seller, who pretends to be blind, shows that deception is a common trait in the urban space. A scene of the Office of Agricultural Economics where so many people are in the queue to obtain job applications presents the image of fierce competition when pursuing a career in the city. In addition, some signifiers of modern culture are used in problematic situations to imply the view that the adoption of a foreign culture can be a source of problems. An example is the Valentine's Day cards bought by Lalita. All of them contain English messages with the image of a rose on the front. Lalita uses them to deceive the gang into believing that she is interested in each of them just for fun, but this causes tension in the cohesion of the gang.

\section{Anueng Khitthueng Pho Sangkhep}

Anueng Khitthueng Pho Sangkhep was created for the nostalgic representation of high school youth. To recall how high school was, the film depicts the unique aspects of Thai students by way of a large group of youth characters whose behavior is not as admirable as those in Bunchu films but appears funny and unique through their group conversations, teasing activities and casual teenage love, all of which are images of the way high school youth acted before the 1990s. However, some ideal features can be detected in these youth characters. These features consist of loyalty to the group to which they belong, non-aggressive reactions during conflicts, unity, absence of delinquency, care and concern for friends, obedience to school teachers and parents, self-improvement and a simple lifestyle where they do not engage in what is considered to be unnecessary consumption.

In terms of the school itself, a typical Thai high school atmosphere is created through a combination of supporting characters, location settings and school traditions. Mrs. Nualsri represents a typical Thai teacher who always opts for fierce and strict control of the students. The educational atmosphere communicates in accordance with mainstream belief study and appropriate recreations as the duty of young people. School elements, such as the sport fields, a flag pole, or the cafeteria, in tandem with general traditions, such as Thai-style uniforms or teaching methods which emphasize lectures more than critical thinking, are common 
elements found in Thai high schools, all of which are incorporated in this film.

Promotion of traditional Thainess, over Thainess in the modern construct, is another way of representing a position that speaks against change. To do this, the film depicts elements that suggest cultural specificity: forgiveness, compromise and interdependence; respect for educational materials; a spirit board as a reflection of the belief in ghosts; Thai style wooden houses; a Thai style minibus (or song thaeo) and pedicab; and a belief in general education, including the belief that youth are not in the proper age for romance. At the same time, a negative representation of modernity is inserted into the story to hint at the negative side of development. These representations include a red demon that connotes the HIV crisis, a cake as a sign of foreign culture, but which causes trouble to people when it explodes, and ruffians who appear in fashionable outfits with props.

\section{Anueng Khitthueng Pho Sangkhep Run Two}

Anueng Khitthueng Pho Sangkhep Run Two is completely different from its prequel in providing a picture of how modern society and the economy bring about social problems, rather than repeating the good memories of high school youth. Two opposing groups of high school students represent these problems. They have a serious conflict with each other and a lack of self-control. They are divided only because their family backgrounds are not the same - with the rich versus the poor. Whether rich or poor, they are equally self-centered, materialistic and preoccupied with a consumer lifestyle. A weak realization of ethical and moral behavior is part of their nature. One of them is obsessed with love, while the rest dream about an unrealistic future. All of these are aspects of youth believed to be derived from the changing way of life and the story makes clear that the central characters experience a bad outcome from such behavior.

Although the youth problem is made evident by way of the central characters, compliance with the expectations of youth can be perceived in this film as well. Ning is a character whose conscientious, diligent and self-controlled features are depicted from the beginning to the end. She experiences no problems like the group of rich and poor students. Other central characters admit to personal change, in conformity with the concept of desirable youth, after realizing the consequences of their misbehavior. They are interdependent, even in the face of their conflict, when it is necessary. Above all, none of them can be considered delinquent, despite their worrisome behavior, because of their detachment from vices. Their roles also promote a belief in education as the duty of youth, while some of them contribute to a portrayal of proper romance for young people.

Similar to all the previous youth films, Anueng Khitthueng Pho Sangkhep Run Two depicts what is considered to be local culture. Although the film relies on a Catholic school as its main location, localization of the school is projected 
through, for instance, the use of terms 'bra-der' and 'mas-ser' when referring to the rector and school teacher. Such local culture is also seen in a form of traditions, locations and props, such as interdependence, Rae's Thai house and the use of a pedicab, all of which suggest Thai cultural specificity. At the same time, the new living context is portrayed as a site of social problems. This is evident in the role of parents who fail to create a proper environment for raising their children or who do not pay proper attention to their children. Other examples of criticism of the modern living context include the character of Kath, whose appearance looks very fashionable but which possesses no ideal features of a Thai girl; a department store as a typical place for consumerism; and the tension of selling soymilk in a prohibited area just to earn enough income.

\section{Chue Chop Chuan Ha Rueang}

Chue Chop Chuan Ha Rueang repeats Bundit's convention of portraying a key young character in accordance with the expected behavior of Thai youth. Throughout the story, Chop is the only character who retains aspects of good youth, while the other characters - even the adults - turn into people who seem unkind, ill-mannered or are amoral. Chop is outstandingly polite and non-violent. His belief in Buddhism is obvious. $\mathrm{He}$ distances himself from all general vices. A public service mind and good attention to social matters are always his concern. Self-development in terms of worldview and courage are part of his character, as well as recognition of the need to avoid sexual relationships. At the end of the story, he promotes the idea of selfsufficiency through his choice of life in the rural village, despite having the chance of obtaining immeasurable wealth from a Northern godfather.

In contrast, retribution is shown whenever the youth characters fail to comply with the desired youth behavior. Narin, Inthuorn and the young riders experience either disappointment or problems after they turn their backs on the prescribed tradition for the young. For example, Narin leaves her family just to pursue her romance but it ends in disappointment and tears. Even Chop can be considered a character designed to communicate this point. He is forced to go through a series of difficulties because he insists on his romance with Inthu-orn, while he is yet to know what love really is, and the story ends with his separation from Inthu-orn.

Chue Chop Chuan Ha Rueang bears a similarity to Anueng Khitthueng Pho Sangkhep Run Two in stressing criticism of modern society. This film focuses on the portrayal of an utterly corrupt society wherein no one is interested in ethical and moral improvement. Inthu-orn and the young motorbike riders concentrate on personal pleasure without any regard for others. Violence is used by a number of characters as a way out of conflict or even in normal situations. Some characters are not hesitant to do anything in exchange for money, even if it is deemed inappropriate. Weakening ethical courage, including the overall image of an unhappy society, is integrated into the story to imply the negative side of socio-economic 
modernity. On the other hand, the state of happiness is made clear in three flashbacks, all of which involve an atmosphere of agriculture and Thai customs. Happiness also appears in the scene of selfsufficiency living at the end. This connotes the idea that maintenance of such Thainess can be the path to happy feelings. Generosity and understanding can be sensed in the Buddhist temple scene. The expected victory over the threats from the antagonists comes after interdependence is practiced by Chop and a group of supporting characters who are not previously acquainted with each other. All these suggest an idea that supports the conservation of Thai cultural identity.

\section{Bunchu I Love Sara Ou}

The role of the central youth character in Bunchu I Love Sara Ou belongs to Bunchu's son, Bunchoke, who emphasizes ruralness as a part of the traditional Thai identity, as well as supporting the idea of proper behavior in youth. Bunchoke maintains his rural manner throughout the story as can be seen in his dialect, naivety and style of clothing. He uses, for instance, a neat shirt with common trousers, unlike the city youth whose outfits always look colorful and stylish. In parallel with his ruralness, he maintains his Buddhist practice and faith and mercy, benevolence, politeness, calmness and friendliness are his consistent nature, which helps him establish friendships with other people easily. $\mathrm{He}$ is deferring and obedient, making him a beloved young man among his seniors. Ethical courage and a public mind are also components of his character, as can be seen in the situation in which he helps Pim escape from ruffians.

Youth, from the ideal perspective, is not only depicted through Bunchoke but also his group - Ning, Aen, Yon, and Prapaan - all of whom have urban origins. All four offer help to Bunchoke despite knowing that they will gain no advantage. They have part-time jobs for their selfsupport but none of them has an arrogant nature. In the scenes of their gatherings, the group interaction through constructive activities, reconciliation after group conflicts, lifestyles deemed appropriate in Thai society and the absence of romantic obsession, are noticeable. It can be said that they all work together to propagate the desirable aspects of youth.

Once more a critical representation of modern society is the technique used to speak against social change. In the urban scenes, the audience can sense a busy lifestyle with all its tensions and unfriendly interaction, and social problems are clearly depicted in these scenes. These problems are delinquency, juvenile offences, the normality of lawlessness, and difficulty in living difficulties. These problems tend to connote the toughness of life in modern society and an ethical and moral decline some believe to have resulted from the recent economic and social development. Interestingly, technology and signs of popular culture appear in scenes where some characters commit criminal acts, which implies a relationship between socio-cultural change and moral problems. Some bits of dialogue by the supporting characters contain an indirect meaning about the 
distortion of democracy in Thai society. One example is the situation where $\mathrm{Pi}$ Pong tells Yoi to stop selling Thai sweets because, for Pi Pong, the sweets are of poor quality. Yoi responds that quality is unimportant as long as his products are still popular. Upon hearing that, Nara asks if Yoi is still concerned about the nation, democracy, and Thainess. Nara continues that, if he is really concerned, he must stop selling the sweets. This dialogue is not necessarily mutually coherent, but seems to reflect on the use of populist policies in Thai politics. Yoi stresses popularity above quality, while Nara mentions nation, democracy, and Thainess in opposition to popularity, which appears intended to remind the audience of the populist policies and their impact on Thai society during the period when Thaksin Shinawatra was in power. As concluded by Laothamatas (2006: 152), populist policies are deficient in genuine value and are often undertaken to the detriment of the extant socio-cultural values.

The images or meanings concerning traditional Thainess are repeatedly featured as if the film is reminding the audience of what 'being Thai' should be. These include the tradition of interdependence and compromise, the agricultural lifestyle, belief in education as the young's supreme duty and the use of Thai identified locations, such as Rajadamnern Avenue or the Chao Phraya River. Localization of foreign traditions emerges in some scenes to suggest the incorporation of some cultural identity into modernity. Examples are the scene of serving American fried rice in Thai-style porcelain and the scene of a birthday party where everyone sings a typical Thai song titled Reward for a Dreamer [รางวัลแด่คนช่างฝัน] instead of Happy Birthday.

\section{Anueng Khitthueng Pen Yangying}

The last film, Anueng Khitthueng Pen Yangying, expresses a view in opposition to the typical behavior of young people seen in the 2000s with the image of the central characters looking quite admirable in a Thai context. The central characters appear as two large groups and share the same features. They all show gratitude to the school from where they graduated. They have good respect for seniority and firm friendships and their lifestyle does not embrace the common activities of young people, such as conspicuous consumption, improper entertainment or any other vices. When the two groups are in a serious conflict, violence is not their option. Instead, then manage the conflict with a rugby match that leads to reconciliation. Forgiveness, unity and interdependence can be detected in their characters. Finally, they are more interested in the matters of their school than in personal romance.

Cultural individuality is represented in many scenes to highlight what is deemed traditional Thainess. The school, Mattayom Wutti-Dhewa Wittaya, is used as a major location, the overall aspects of which represent a local Thai school existing in the old days. The school has classic components, such as old wooden buildings, a tall flag pole with amplifiers hanged from the buildings, a student society and joyful friendship, and teaching methods that emphasize lecture and rote 
memorization. In addition to the school, a combination of some settings, props and characters is used in the film to evoke a sense of Thainess. Sethawat is the heroic character who solves the problem at the end. $\mathrm{He}$ and his house represent the lifestyle of Thai people during the period of Kings Rama V and VI. A belief in ghosts and the spirit of a legendary ghost named Mali are incorporated into the story to indicate Thai beliefs from a supernatural angle. The name of one central character, Ya Lae, which has a meaning concerning loyalty to the nation by making reference to the concept of the three pillars, contributes to the evocation of Thainess as well.

Unlike all the previous youth films, Anueng Khitthueng Pen Yangying features a tacit view against modernity with its strong emphasis on the influence of capitalism. The film shows that, amid the capitalistic current, only profitable operations are allowed to survive. In this way, the school is about to be demolished by a businessman - for the construction of a department store, regardless of its potential use for educational purposes. None of the relevant people, such as the alumni, cares about the fate of the school because it is understood, they accept the way of capitalism. Above all, the foundation administrators who supervise the school make clear that, without money, they can do nothing to continue the school's operation even if they wanted to.

\section{Conclusion}

The preceding discussion explains the themes of representations in Bundit's youth films with reference to changes in Thai society. Based on a synthesis of these themes, all ten films are similar in their attempts to address the impact of change. They can be divided into two groups - Bunchu and non-Bunchu films. The Bunchu films focus on the portrayal of outstandingly ideal youth characters in the context of Thai living and underline agricultural society as a prominent social identity. Problems of urbanization appear in most of the Bunchu films in order to reject the process of development that disregards the rural sector.

The non-Bunchu films, which include the Anueng films, Khu Wun Wai Wan, and Chue Chop Chuan Ha Rueang, do not rely on a plot about 'rural versus urban', as is the case in the Bunchu series, and most of the key characters in this group are not as amiable as Bunchu or Bunchoke. However, the group of Anueng films reflects a sense of localism through the picture of a Thai high school. Anueng Khitthueng Pho Sangkhep Run Two is more specific than the other two in depicting the problems facing youth in the modern society, as, also, do Khu Wun Wai Wan and Chue Chop Chuan Ha Rueang.

Nevertheless, all these youth films promote the concept of ideal youth through their central characters. The central characters either have ideal qualities in themselves, as shown by Bunchu and Moree, or they suffer by breaking the rules of what is considered good youth behavior, followed by selfimprovement, as exemplified by Meen in Khu Wun Wai Wan or the key high school students in Anueng Khitthueng Pho 
Sangkhep Run Two. The ideal attributes that are repeatedly suggested are responsibility for education, awareness of appropriateness in youth romance, interdependence, group unity, forgiveness, compromise and a strong belief in Buddhism. Interestingly, heroism is absent in every film with, instead, the incorporation of mutual assistance in tackling conflicts. In all the Anueng films, a protagonist can not really be identified because the main characters come as a group conveying a sense of togetherness. These images contrast clearly with the individualistic nature of youth in the 1980s-2000s, while conforming to the proposal concerning ideal Thai youth as presented in Pienchob's research (1982), such as maintaining discipline and selfcontrol, being accountable, or creative.

Along with the promotion of the behavior of ideal youth, images of socio-economic modernity are portrayed either as undesirable or as a source of problems. An example is Chue Chop Chuan $\mathrm{Ha}$ Rueang where some characters are overly obsessed with money and personal pleasure and cannot think about morality and taboos, or Bunchu I Love Sara Ou in which the city is full of with juvenile delinquency. Sometimes, signifiers suggestive of modernity appear in scenes of conflicts or bad situations as if they are telling the audience that there exists a relationship between socio-cultural modernity and behavioral and attitudinal problems, The use of a cake to cause trouble to a group of student in Anueng Khitthueng Pho Sangkhep is a prime illustration of this idea. One can interpret this as a message that the recent social and economic change should be reconsidered.

The research indicates, also, that all of Bundit's youth films support the idea of conserving what is deemed to be good Thai cultural identity. Images of being Thai are represented frequently in connection with the central or important characters, particularly the decent characters, so that being Thai in the right way can be easily recognized by the audience. Sometimes, being Thai is depicted in combination with a happy or positive mood, such as the friendly interaction in the rural village in the Bunchu films. Sometimes, signifiers of being Thai provide positive meanings, such as the character of Sethawat in Anueng Khitthueng Pen Yangying who represents past Thai culture, but since he is the one to save the school from the demolition, he projects Thainess from a superior angle. This can be seen as an attempt to speak against the idea that the old cultural identity is outdated and of no importance to modern society.

Representations that tend to support the recent social and economic changes in Thai society with respect to the new way of living, the new economy and the new youth culture, are not evident in Bundit's youth films. This can be recognized as part of Bundit's signature, as well as way of portraying his thinking, that is as a form of his message of resistance to change. Part of the plotline in the sixth Bunchu film, when Bunchu decides to forego a job in Bangkok and return to the village to be a rice farmer, points to the significance and the merits of an agrarian society from an 
Film or Flick?

idealized, even bucolic, perspective. It is sufficient to say that Bundit represents those who favor the idea of localism. His youth films can be seen as a case study for understanding how the film medium can be used to provide a reaction to serious social issues, such as the impact of globalization or the detrimental aspects of new youth culture.

It should be noted, however, that Bundit's youth films do not show a resistance towards the trends of globalization in an extreme way, but rather try to soften the current trend of being 'global' with positive images of being local. Each film offers an idea of conserving what is deemed a socio-cultural identity, while allowing many of the key characters to embrace the modern trend of living in some measure, as exemplified by the case of Bunchu who studies pesticides - a modern area of knowledge - in pursuit of bettering cultivation in his village.

With a focus on films directed by Bundit Rittakol, this study makes clear that his youth films, despite their popularity, were not made for merely commercial return or to please the mainstream audience. All the films are filled with a conviction and serious messages about worldviews regarding the preservation of the sociocultural norm, rather than promoting the new trends of modern living. While the existing literature about Bundit's youth films argue that his youth films promote desired values, such as generosity or friendship, this research gives a new depth of understanding that suggests that his films contain a message promoting localization to counter the current of modernism and/or globalization and that is reflection of resistance.

\section{Appendix}

\section{Khu Wun Wai Wan}

Meen is a homeless delinquent who has the chance to be friends with a pleasant, but eccentric young man named Jeab. He has feelings for Jaeng (Jeab's sister), while Jeab himself fancies Aom (Jaeng's close friend). The two girls dislike the boys because of their unimpressive natures. Jeab and Meen are, however, accepted as their boyfriends after they try very hard. Then, they share good moments and hardships together, leading to their learning of maturity.

\section{Bunchu Phu Narak}

A young, rural man named Bunchu moves to Bangkok to take the university entrance exam as desired by his mother, Bunlom. There, he experiences a warm friendship with Yoi, Nara, Chuey, Kummoon and Waiyakorn, as well as developing a crush on Moree. He is, at first, distracted by his romantic feelings but becomes more diligent after Bunlom expresses her concerns about his studies. Despite working hard, Bunchu fails the exam. Bunchu forgets all his disappointment when he hears that Moree has been abducted. He risks his life to save her with help from the group.

\section{Bunchu Two, Nongmai}

Bunchu makes the decision to return to Bangkok for another try at taking the 
university entrance exam. He reunites with everyone, with Prapun added to the group. They all cooperate in fundraising for Moree's development club at her school. Then, Bunchu gets to know Bunma and becomes friends with him. On Valentine's Day, Bunchu decides to give Moree a red rose as a sign of his love but learns that she only thinks of him as a close friend, so Bunchu instead focuses hard on achieving his educational target. In the meantime, Bunma steals the development club's money prior to Bunchu's exam. Bunchu, Moree, and the group help each other to get back the money. Bunma confesses that he did not want to do it, but did so because of his poor family. Bunchu attends the exam for the second time but fails again. However, hours later, a telegraph is delivered to inform that he has finally been granted a place at Kasetsart University because some applicants have withdrawn.

\section{Bunchu Five, Nueahom}

At Kasetsart University, Bunchu has the opportunity to get to know $\mathrm{Ou}-\mathrm{a}$ courteous first-year student who has just lost her chance to another student, Sayun, of obtaining a student grant. Bunchu learns that Sayun is misusing the money, so he is determined to enter the race for student president to pave the way for an amendment of the grant regulations. Unfortunately, Bunchu is defeated in the election. He meets the sponsors of the grants himself to reveal that their money is getting into the wrong hands. To back his words, Bunchu and the group take a photo of Sayun buying beer with the money. Ou receives approval and is awarded the money at long last but she moves to the UK after her financial problem is unexpectedly solved. She thanks Bunchu, as well as telling him that the grant should be given to the other candidates who need the money.

\section{Bunchu Six, Lok Ni Di Ok Sutsuai Narak Nayu Tha Ngui}

Bunchu is in his final year while many in his group have already started working. In addition to studying, Bunchu has to look after Tongdee - his courteous but naïve cousin who has just begun his first year at Kasetsart University. Everything is going all right until the arrival of Lalita who keeps flirting with each of the members of the group just for fun, causing the group to think that Lalita is in love with each of them and resulting in the group's disintegration. Bunchu is the only person unaffected by Lalita's deception, so he decides to reveal her dishonesty to restore the group's unity. Lalita dislikes Bunchu and tries in every way to disadvantage him. A chaotic fight between Lalita's team and Bunchu's group in unavoidable but Lalita is defeated in the end.

\section{Anueng Khitthueng Pho Sangkhep}

The story begins with some science students embarrassing some art students, leading to a series of childlike revenge ploys between the two groups. During this unfriendly interplay, Tong-Aeg is admitted into the school as an intern teacher. One of the art students named Taew falls in love with him at first sight. The conflict between the two groups, however, fades away when the science students rescue the 
art students from a combined attack outside their school. The situation is going well until Jong - a student who has fallen in love with Taew - decides to hurt Tong-Aeg. Taew tries to commit suicide by drugging herself after learning that Tong-Aeg is about to marry. The cost of her action is Tong-Aeg's suspension from his internship. These troubles encourage all the students to become aware of their immaturity and they develop sincere friendships that last until adulthood.

\section{Anueng Khitthueng Pho Sangkhep Run Two}

Two groups of high school student are at odds with each other because of their different family backgrounds -rich versus poor. The school rector forces them to join a marching band so that they can learn unity and amity. However, the two sides keep opposing each other and some of them do not concentrate on practicing. Unexpectedly, the band is scheduled to perform in the provincial fair, followed by the school fair. The band is not well equipped, resulting in a shameful performance at the provincial fair. All the students repent their misbehavior. They become self-disciplined before encountering success at the school fair, as well as in other grand competitions.

\section{Chue Chop Chuan Ha Rueang}

A polite and nonviolent young man named Chob is in love with Inthu-orn. $\mathrm{He}$ is forced to take a challenge by Inthu-orn's father in which he must make a journey to Chiang Rai and, on the way, engage in fights with anyone to show that he is manly enough to be her lover. Chop departs Bangkok with a stranger named Narin who tries her best to help Chob accomplish the challenge. They both fail repeatedly until they experience a frightening threat from a cruel godfather. They depend on help from people with whom they are not acquainted leading to their victory. This impresses Inthu-orn's father greatly. In spite of the mission being completed, Chob decides to be with Narin rather than Inthu-orn.

\section{Bunchu I Love Sara Ou}

Bunchoke, the son of Bunchu and Moree, is sent to Bangkok to prepare for the university entrance exam. Moree asks Prapun and Nara to look after Bunchoke. However, Bunchoke is drugged and loses his belongings upon his arrival in Bangkok. After waking up, Bunchoke meets Prapun and Nara who are searching for him with the help of Prapaan (Prapun's son), Ning (Nara's daughter) and Yon (Yoi's son). Prapun and Nara leave Bunchoke with the three. Later, Aen (Ning's workmate) offers everyone accommodation in her grandmother's house, where they have fun together. One day, Bunchoke has the chance to meet Pim, who was involved with the loss of his belongings. He tries to get them back, but is unsuccessful. On the examination day, Pim is abducted by ruffians in front of Bunchoke who makes the decision to skip his exam to help Pim. Ning, Aen, Yon and Prapaan join the rescue too. Finally, Pim returns the bag to Bunchoke and gives up her criminal behavior. 
MANUSYA: Journal of Humanities Regular 19.1, 2016

\section{Anueng Khitthueng Pen Yangying}

The story begins with memories of high school where the students enjoyed their early education. The focus is a group of students from the art and science discipline. The art students often irritate the science students and the science students are never hesitant to take revenge. Then, the film cuts to the present day, and the art students, who already have become university students, being informed that a businessman has bought their school and is aiming to demolish it to build a department store. Because of their high regard for the school, the art students decide to camp out for a few nights in the school area to recall the atmosphere one last time. There, they meet the science students doing the same thing with the same intention. Both sides spend time as enemies and friends until a group of demolition workers reaches the school. They come to the decision to try to maintain the school's operations and with their tireless attempts, success comes in the end.

\section{References}

Boonyaketmala, Boonrak. 2009. The

Seventh Art: For the Culture of Film

Criticism (ศิลปะแขนงที่เจ็ด: เพื่อวัฒนธรรมแห่งการ

วิจารณ์ภาพยนตร์). Bangkok: Public Bookery. (In Thai)

Boribanbanpotkate, Saksri, and Ptanawanit, Surapone. 1995. The Tendency of Change in Misbehaviour among Thai Children and Youth (แนวโน้มการเปลี่ยนแปลง ของพฤติกรรมการกระทำผิดของเด็กและ
เยาวชนไทย). Bangkok: Thai Khadi

Research Institute, Thammasat University. (In Thai)

Changrean, Paibul. 1971. The Aspects of Thai Society and Administration (ลักษณะ สังคมและการปกครองของไทย). Bangkok: Thai Watana Panich Press Co., Ltd. (In Thai)

Chamduang, Nibhondh. 1986. The Movement of the Young in the Past Two Decades in the Eye of Sor Sivaraksa (ขบวนการคนหนุ่มสาวใน รอบ 2 ทศวรรษตามทัศนะส. ศิวรักษ์). Bangkok:

Tienwan Publishing House, Ltd. (In Thai)

Chummuangpak, Manoch. 2004. The Narrative of Thai Popular Comedy Film Series "Boonchoo" and the Director's Creative Approaches (การเล่า เรื่องของภาพยนตร์ตลก ไทยยอดนิยมชุด "บุญชู" กับ การสร้างสรรค์ของผู้กำกับภาพยนตร์). Master's thesis, Chulalongkorn University. (In Thai)

Driscoll, Catherine. 2011. Teen Film: A Critical Introduction. Oxford: Berg.

Kohpaiboon, Archanun. 2006. Multinational Enterprises and Industrial Transformation: Evidence from Thailand. Cheltenham: Edward Elgar Publishing Limited.

Kolker, Robert. 2006. Film, Form and Culture. New York: McGraw-Hill.

Krongkaew, Medhi. 2009. Thai Economy in 2005: Facing an Uncertain Future? In Thaksin's Thailand: Populism and 
Polarization, edited by Funston, John, pp. 26-48). Bangkok: Institute of Security and International Studies.

Kumprabhan, Sappasit, and Kaewseenuan, Sujittra. 2004. Violence towards Children and Youth: A Reflection of Violence in Thai Society (ความรุนแรงต่อเด็ก และเยาวชน : ภาพสะท้อนความรุนแรงของ สังคมไทย). In Thai Youth in the Gig Generation (เด็กไทยวัยกิ๊ก), edited by Saenjairak, Jurairat, pp. 37-50. Bangkok: Satabun Witeetas. (In Thai)

Laird, John. 2000. Money Politics, Globalization, and Crisis: The Case of Thailand. Singapore: Graham Brash Pte Ltd.

Laothamatas, Anek. 2006. ThaksinaPopulism: Meaning, Problem, and Solution (ทักษิณา-ประชานิยม : ความหมาย ปัญหา และทางออก). Bangkok: Bangkok: King Prajadhipok's Institue. (In Thai)

Nakornthap, Amornwit. 2004. Thai Youth Crisis Can Still Be Solved (วิกฤติวัยุุ่นไทย ยังไม่สายเกินแก้). In Thai Youth in the Gig Generation (เด็กไทยวัยกิ๊ก), edited by Saenjairak, Jurairat, pp. 15-63. Bangkok: Satabun Witeetas. (In Thai)

Piampongsarn, Preecha, and Kaewthep, Kanjana. 2000. Concepts and Dreams by 14 Senior Thinkers of Thailand (แนวคิดและความใฝ่ฝึนของ 14 นักคิดอาวุโสไทย). $\mathrm{In}$ A New Route of Development:
Methodologies of Thai Social Studies (วิถีใหม่แห่งการพัฒนา : วิธีวิทยาศึกษาสังคมไทย), edited by Piampongsarn, Preecha, Kaewthep, Kanjana, and Kaewthep, Kanoksak, pp. 155-176. Bangkok: Faculty of Economics, Chulalongkorn University. (In Thai)

Pienchob, Sucharit. 1982. Desirable Characteristics of Thai Youth (คุณลักษณะ ของเยาวชนไทยที่พึ่งปรารถนา). Bangkok: Chulalongkorn University. (In Thai)

Puapongsakorn, Nipon. 1999. Some Lessons from the Thai Industrialization and the King's Philosophy of the "Sufficiency Economy" (การพัฒนา อุตสาหกรรมไทยกับแนวคิดเรื่องเศรษฐูกิจพอเพียง). Paper presented at the 1999 Academic Seminar by The Chaipattana Foundation, National Research Council of Thailand, National Institute of Development Administration, Office of the National Economic and Social Development Board, and Thailand Development Research Institute. (In Thai)

Sengpracha, Narong. 2001. Thai Living (วิถี ๆทย). Bangkok: Odeon Store. (In Thai)

Setihoe, Rajanikorn. 1989. The structure of Thai Society and Culture (โครงสร้าง สังคมและวัฒนธรรม ไทย). Bangkok: Thai Watana Panich Press. (In Thai)

Sukkumnoed, Decharut. 2011. Urban Living in Support of the Rural (วิถีเมืองที่ เกื้อกูลชนบท). In Rural and Urban: To the 
Happy Living (ชนบทกับเมือง : สู่ความอยู่มีมีสุข), edited by Kanchanapan, Anan, et al., pp. 69-90. Bangkok: Suan-NgenMeema Publishing. (In Thai)

Thasanabanchong, Cheeraboonya. 1991.

The Analytical Study of the

Characteristics of Thai Popular Youth

Movies (การศึกษาเชิงวิเคราะห์ลักษณะของภาพยนตร์

ไทยยอดนิยมประเภทวัยรุ่น). Master's thesis, Chulalongkorn University, Bangkok. (In Thai)

Thasanabanchong, Cheeraboonya. 2010. A Study of Themes in Contemporary Thai Teenage Films. In 2010 International Seminar and Screening of Thai Cinema, edited by Wiwatsinudom, Raksarn, et al., pp. 228-233. Bangkok: 21 st Century Publishing Company Inc. Ltd.

The Board of Educational and Training

Development for Teenagers. 1992.

Youth as A Creative Age for Thai

Society: Suggestions for the

Development of Youth (วัยรุ่นวัยสร้างสรรค์เพื่อ

สังคมไทย : ข้อเสนอแนะเชิงนโยบายเพื่อการพัฒนาเด็ก

วัยรุ่น) (In Thai) 